\title{
Task Monitor Scale
}

National Cancer Institute

\section{Source}

National Cancer Institute. Task Monitor Scale. NCI Thesaurus. Code C121470.

A rating scale included in the Behavior Rating Inventory of Executive Function (BRIEF) that reflects the ability to keep track of one's problem-solving success or failure, and to identify and correct mistakes during performance of a goal. 